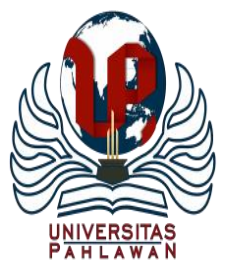

Edukatif : Jurnal Ilmu Pendidikan Volume 3 Nomor 2 Tahun 2021 Halm 412 - 420 EDUKATIF: JURNAL ILMU PENDIDIKAN

Research \& Learning in Education

https:/ledukatif.org/index.php/edukatif/index

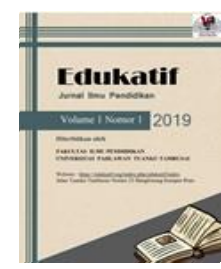

\title{
Hubungan Kesiapan Mengajar dan Proses Praktik Pengalaman Lapangan dengan Keterampilan Dasar Mengajar Mahasiswa Pendidikan Biologi
}

\author{
Agus Maramba Meha ${ }^{1 凶}$, Novi Ivonne Bullu² \\ Pendidikan Biologi, Universitas Kristen Artha Wacana ${ }^{1,2}$ \\ E-mail : us.meha17@ gmail.com ${ }^{1}, \underline{\text { novibulu@gmail.com }}^{2}$
}

\begin{abstract}
Abstrak
Mahasiwa calon guru harus menguasai keterampilan dasar mengajar yang diperoleh melalui program pengajaran dan pelatihan di kampus maupun praktik lapangan di sekolah. Penelitian bertujuan mencari hubungan antara kesiapan mengajar dan pelaksanaan pengalaman praktik lapangan dengan keterampilan dasar mengajar mahasiwa. Penelitian $e x$ post facto dengan desain korelasi, variabel $\left(\mathrm{X}_{1}\right)$ kesiapan mengajar dan $\left(\mathrm{X}_{2}\right)$ pelaksanaan pengalaman lapangan $(\mathrm{PPL})$ dan keterampilan dasar mengajar (Y). Sampel adalah mahasiswa program studi pendidikan biologi yang melaksanakan PPL berjumlah 26 orang. Pengumpulan data menggunakan angket, data dianalisis dengan statistik inferensial berbantuan SPSS. Hasil pengujian hipotesis pertama menunjukkan nilai sig $=0,003$ lebih kecil dari $\alpha=0,05$ terdapat hubungan yang positif dan signifikan antara kesiapan mengajar dengan keterampilan mengajar mahasiswa PPL, dengan koefisien hubungan sedang. Pengujian hipotesis kedua menunjukkan nilai sig $=0,005$ lebih kecil dari $\alpha=0,05$ Artinya terdapat hubungan yang positif dan signifikan antara proses pelaksanaan PPL dengan keterampilan dasar mengajar, kooefesien hubungan sedang. hipotesis ketiga menunjukkan nilai sig. F Perubahan 0,002 lebih kecil dari nilai $\alpha=0,05$ Hal ini berarti terdapat hubungan yang positif dan signifikan antara kesiapan mengajar dengan proses pelaksanaan PPL dengan keterampilan dasar mengajar mahasiswa PPL. Semakin baik kesiapan mengajar mahasiswa dalam pelaksanaan PPL maka akan semakin meningkat keterampilan dasar mengajarnya.
\end{abstract}

Kata Kunci: Kesiapan Mengajar, Praktik Pengalaman Lapangan, Keterampilan Mengajar Dasar.

\begin{abstract}
Prospective teacher students have to master basic teaching skills which are acquired through training programs in campus as well as teaching practice at schools. The study aims to find the relationship between teaching readiness and the implementation of teaching practice experiences with the basic teaching skills of prospective teacher students. This ex post facto research set correlation design, variable $\left(X_{1}\right)$ teaching readiness and $\left(X_{2}\right)$ implementation of field experience $(P P L)$ and basic teaching skills $(Y)$. The sample consisted of 26 students of the biology education program who were taking teaching practice or PPL. The data were collected using a questionnaire, the data were analyzed using inferential statistics assisted by SPSS. The results of the first hypothesis show that the value of sig $=0.003$ is smaller than $\alpha=0.05$. There is a positive and significant relationship between teaching readiness and teaching skills of prospective teacher students, with a moderate correlation coefficient. The second hypothesis testing shows that the value of sig $=0.005$ is smaller than $\alpha=0.05$. This means that there is a positive and significant relationship between the teaching practice process and basic teaching skills, the coefficient of the relationship is moderate. The third hypothesis shows the sig value. $F$ The change of 0.002 is smaller than the value of $\alpha=0.05$. It means that there is a positive and significant relationship between teaching readiness and the teaching practice process with the basic teaching skills of training students. The better the students' teaching readiness in teaching practice, the better their basic teaching skills will be.
\end{abstract}

Keywords: Teaching Readiness, Teaching Practice Experience, Basic Teaching Skills.

Copyright (c) 2021 Agus Maramba Meha, Novi Ivonne Bullu

$\triangle$ Corresponding author

Email : us.meha17@gmail.com

DOI : https://doi.org/10.31004/edukatif.v3i2.323

ISSN 2656-8063 (Media Cetak)

ISSN 2656-8071 (Media Online)

Edukatif : Jurnal Ilmu Pendidikan Vol 3 No 2 Tahun 2021 p-ISSN 2656-8063 e-ISSN 2656-8071 
413 Hubungan Kesiapan Mengajar dan Proses Praktik Pengalaman Lapangan dengan Keterampilan Dasar Mengajar Mahasiswa Pendidikan Biologi - Agus Maramba Meha, Novi Ivonne Bullu

DOI: https://doi.org/10.31004/edukatif.v3i2.323

\section{PENDAHULUAN}

Guru memiliki tugas utama mendidik, mengajar, membimbing, mengarahkan, melatih, menilai dan mengevaluasi peserta didik, dalam melaksanakan tugas utama tersebut guru harus memiliki kompetensi seperti kompetensi pedagogik, kompetensi professional, kompetensi sosial, kompetensi kepribadian. Salah satu kompetensi yang menjadi perhatian dalam proses pembelajaran yaitu kompetensi pedagogik yang merupakan kemampuan guru dalam memahami peserta didik, perencanaan dan pelaksanaan pembelajaran, evaluasi hasil belajar, dan pengembangan potensi peserta didik.

Kesiapan guru sangat diperlukan agar dalam pelaskananaan pembelajaran dapat dilakukan dengan baik dan dapat tercapainnya tujuan pembelajaran yang telah ditetapkan. Menurut Slameto (2013 dalam Azizah \& Rahmi, 2019) menjelaskan kesiapan adalah keseluruhan kondisi individu yang membantunya siap untuk memberikan respon atau jawaban dengan cara tertentu terhadap suatu situasi. Lebih lanjut Wardhani, (2020) menegaskan seorang guru akan mempunyai kesiapan mengajar, apabila ia mempunyai kompetensi kompetensi yang harus dikuasai oleh seorang pendidik. Merujuk pada kedua pendapat diatas dapat dikatakan bahwa seorang guru sebelum melaksanakan pembelajaran perlu mempersiapkan segala kondisi baik mental, fisik, social dan emosional sehingga mampu dalam melaksanakan tugas pembelajaran dalam situasi apapun atau dengan kata lain guru wajib mempunyai kompetensi dan melakukan kesiapan sebelum mengajar.

Salah satu kompetensi yang perlu dipersiapkan dan wajib dimiliki oleh guru adalah keterampilan dasar mengajar. Keterampilan dasar mengajar merupakan keterampilan yang berkaitan dengan semua aspek kemampuan guru yang berkaitan erat dengan berbagai tugas guru yang berbentuk keterampilan dalam rangka memberi rangsangan dan motivasi kepada siswa untuk melaksanakan aktuvitas oleh guru adalah ketermpilan untuk membimbing, mengarahkan, membangun siswa dalam belajar guna mencapai tujuan pendidikan yang telah ditentukan secara terpadu, (Wahyulestari, 2018). Selanjutnya Samson \& Vyjayanthi, (2013) mengatakan bahwa keterampilan dasar mengajar merupakan kegiatan yang koheren oleh guru dengan pengajaran yang spesifik dan prosedur yang dapat digunakan guru di ruang kelasnya. Adapun keterampilan dasar mengajar yang harus dikuasai oleh guru seperti keterampilan bertannya, keterampilan mengadakan variasi, keterampilan memberi penguatan, keterampilan menjelaskan, keterampilan membuka dan menutup pembelajaran, keterampilan membimbing diskusi kelompok kecil, keterampilan mengelola kelas, dan keterampilan mengajar kelompok kecil dan perorangan.

Melihat kompetensi yang harus dikuasai oleh guru dalam melaksanankan pembelajaran maka lembaga pendidikan \& tenaga kependidikan (LPTK) harus mempersiapkan mahasiswa calon guru secara baik sejak berada dibangku perkuliahan dan memberikan kesempatan kepada mahasiswa untuk melakukan praktik pengalaman lapangan (PPL) di sekolah. PPL merupakan mata kuliah yang wajib ditempuh oleh mahasiswa calon guru, mata kuliah PPL terbagi menjadi dua yaitu matakuliah pengajaran mikro (microteaching) dan PPL. Praktik Pengalaman Lapangan merupakan serangkaian kegiatan yang diprogramkan bagi siswa calon guru yang meliputi latihan mengajar maupun latihan di luar mengajar sebagai ajang untuk membentuk dan membina kompetensi-kompetensi professional yang disyaratkan oleh pekerjaan guru atau kependidikan yang lain. Sasaran yang ingin dicapai adalah pribadi calon pendidik yang memiliki seperangkat pengetahuan, keterampilan, nilai dan sikap, serta pola tingkah laku yang diperlukan bagi profesinya serta cakap dan tepat menggunakannya di dalam penyelenggaraan pendidikan dan pengajaran, baik di sekolah maupun di luar sekolah (Hamalik, 2010 dalam Hapsari \& Widhianningrum, 2013).

Program studi pendidikan biologi Universitas Kristen Artha Wacana merupakan salah satu lembaga LPTK yang menyiapkan tenaga pendidik atau calon guru. Persiapan calon guru dilakukan melalui berbagai program pengajaran dan pelatihan di kampus maupun praktik lapangan yang dilakukan di sekolah dalam kegiatan PPL. Kegiatan ini perlu dilakukan secara baik dengan harapan mahasiswa calon guru dapat memiliki 


\section{Hubungan Kesiapan Mengajar dan Proses Praktik Pengalaman Lapangan dengan Keterampilan Dasar Mengajar Mahasiswa Pendidikan Biologi - Agus Maramba Meha, Novi Ivonne Bullu \\ DOI: https://doi.org/10.31004/edukatif.v3i2.323}

keterampilan dasar mengajar yang baik dan juga kompetensi lainnya. Berdasarkan hasil pengamatan selama proses pembelajaran microteaching, menunjukan keterampilan dasar mengajar mahasiswa tergolong rendah, hal ini disebabkan terbatasnya waktu dan kesempatan dalam melatih diri untuk meningkatkan keterampilan dasar mengajar. Dengan adanya program PPL mahasiswa mempunyai waktu yang cukup banyak untuk mengasah keterampilannya dalam pengajaran serta secara langsung mahasiwa diperhadapkan dengan situasi pembelajaran yang sebenarnya di sekolah. Sehingga dengan situasi tersebut mengharuskan mahasiswa untuk melakukan pesiapan mengajar yang lebih baik. Sejalan dengan pendapat Sumarni, (2020) menjelaskan bahwa kegiatan PPL dilakukan untuk dapat memberikan pengalaman belajar bagi mahasiswa terutama dalam hal pengalaman mengajar, memperluas wawasan, melatih dan mengembangkan kompetensi yang diperlukan dalam bidangnya, meningkatkan keterampilan, kemandirian, tanggung jawab, dan kemampuan dalam memecahkan masalah.

Berkaitan dengan hal yang sudah dipaparkan maka sangat diperlukan pelaksanaan praktik pengalaman (PPL) perlu dirancang secara baik serta mahasiswa dapat melakukan persiapan sebelum mengajar sehingga keterampilan dasar mengajar mahasiswa semakin baik. Keterampilan dasar mengajar mahasiswa calon guru dapat disiapkan sejak awal mulai dari proses perkuliahan dikelas dan juga meberikan kesempatan untuk melakukan Praktik pengalam lapangan disekolah dengan proses bimbingan dari guru pamong dan dosen pembimbing. Namun yang terjadi mahasiwa kurang mendapatkan proses bimbingan yang intensif dalam melakukan latihan praktik di laboratorium microteaching, hal ini dikarenakan keterbatasan waktu. Dengan adanya PPL mahasiwa dapat menggunakan kesempatan praktik ini untuk mengasah dan meningkat keterampilan dasar mengajar. Penelitian ini bertujuan untuk melihat: (1) hubungan antara kesiapan mengajar mahasiswa dengan keterampilan dasar menagajar mahasiswa. (2) hubungan antara proses praktik pengalaman lapangan dengan keterampilan dasar menagajar mahasiswa. (3) hubungan secara bersamaan kesiapan mengajar mahasiswa dan proses praktik pengalaman lapangan dengan keterampilan dasar menagajar mahasiswa.

\section{METODE PENELITIAN}

Penelitian ini termasuk dalam jenis penelitian ex post facto dimana rangkaian variable-variabel bebas telah terjadi, dalam hal ini pelaksanaan PPL dan kesiapan mengajar telah dilaksanakan oleh mahasiswa selama praktik pengalaman lapangan disekolah. Penelitian ini menggunakan desain korelasi atau mencari hubungan antar variabel. Dengan menggunakan dua variable bebas yaitu $\left(\mathrm{X}_{1}\right)$ kesiapan mengajar dan $\left(\mathrm{X}_{2}\right)$ pelaksanaan Praktik pengalaman lapangan dan variable terikatnya adalah keterampilan dasar mengajar (Y). Penelitian dilakuakan pada tahun ajaran 2018/2019 semester genap pada sekolah sekolah mitra Praktik Pengalaman Lapangan (PPL) di Kota Kupang Propinsi Nusa Tenggara Timur (NTT). Populasi dalam penelitian ini adalah seluruh mahasiswa Program Studi Pendidikan Biologi yang sedang melaksanakan praktik pengalaman lapangan (PPL) berjumlah 26 orang. Data penelitian dikumpulkan menggunakan angket, data kesiapan mengajar dan pelaksanaan praktik pengalaman lapangan diisi oleh mahasiswa PPL, dan data keterampilan dasar mengajar diisi oleh guru pamong. selanjutanya data yang diperoleh dianalisis dengan statistik inferensial berbantuan SPSS menggunakan analisis korelasi product moment kemudian dilanjutkan dengan analisis korelasi ganda serta juga menggunakan uji t untuk mengukur signifikasi dari variable penelitian.

\section{HASIL DAN PEMBAHASAN PENELITIAN}

Hasil uji normalitas data menunjukan bahwa data kesiapan mengajar, praktik pengalaman lapangan, dan keterampilan dasar mengajar berdistribusi normal karena nilai sig lebih besar dari 0,05. Artinya bahwa selanjutnya dilakukan uji hipotesis. 
415 Hubungan Kesiapan Mengajar dan Proses Praktik Pengalaman Lapangan dengan Keterampilan Dasar Mengajar Mahasiswa Pendidikan Biologi - Agus Maramba Meha, Novi Ivonne Bullu

DOI: https://doi.org/10.31004/edukatif.v3i2.323

Table 1. Hubungan Antara Kesiapan Mengajar Dengan Keterampilan Dasar Mengajar

\begin{tabular}{llrr}
\hline & & $\begin{array}{l}\text { Kesiapan } \\
\text { Mengajar }\end{array}$ & \multicolumn{2}{l}{$\begin{array}{l}\text { Ketrampilan } \\
\text { Dasar } \\
\text { Mengajar }\end{array}$} \\
\cline { 2 - 4 } $\begin{array}{l}\text { Kesiapan } \\
\text { Mengajar }\end{array}$ & $\begin{array}{l}\text { Pearson } \\
\text { Correlation }\end{array}$ & 1 & $.559^{* *}$ \\
& Sig. (2-tailed) & & .003 \\
& $N$ & 26 & 26 \\
Ketrampilan & Pearson & $.559^{* *}$ & 1 \\
Dasar & Correlation & & \\
Mengajar & Sig. (2-tailed) & .003 & 26 \\
\hline
\end{tabular}

**. Correlation is significant at the 0.01 level (2-tailed).

Hasil uji hiipotesis pertama menunjukkan Nilai sig $=0,003$ lebih kecil dari $\alpha=0,05$ berarti ada hubungan positif dan signifikan antara kesiapan mengajar dengan keterampilan mengajar mahasiswa PPL. Besarnya koefisien korelasi $=0,559$ Berada pada kategori sedang. Besarnya kontribusi variable kesiapan mengajar terhadap keterampilan dasar mengajar mahasiswa PPL sebanyak:

$$
\begin{aligned}
\mathrm{KP} & =r^{2} \times 100 \% \\
& =0,559^{2} \times 100 \% \\
& =31,2 \%
\end{aligned}
$$

Artinya keterampilan mengajar mahasiswa PPL ditentukan oleh 31,2\% kesiapan mengajar mereka dan

\begin{tabular}{|c|c|c|c|c|c|c|c|}
\hline \multirow[t]{2}{*}{ Model } & & \multicolumn{2}{|c|}{$\begin{array}{l}\text { Unstandardized } \\
\text { Coefficients }\end{array}$} & \multirow{2}{*}{\begin{tabular}{|c|}
$\begin{array}{l}\text { Standardized } \\
\text { Coefficients }\end{array}$ \\
Beta
\end{tabular}} & \multirow{3}{*}{$\mathbf{T}$} & & \multirow[b]{2}{*}{ Sig. } \\
\hline & & B & Std. Error & & & & \\
\hline \multirow[t]{2}{*}{1} & (Constant) & 17.990 & 34.780 & & & -.517 & .610 \\
\hline & $\begin{array}{l}\text { Kesiapan } \\
\text { Mengajar }\end{array}$ & 1.477 & .447 & .559 & & 3.302 & .003 \\
\hline
\end{tabular}
kontribusi variable lain sebesar $100 \%-31,2 \%=68,8 \%$

Table 2. Koefesien regresi $\left(\right.$ Coefficients $\left.^{\mathrm{a}}\right)$

Dependent Variable: Ketrampilan Dasar Mengajar

Tabel di atas menginformasikan model persamaan regresi yang diperoleh dengan koefisien konstanta dan koefisien variabel yang ada di kolom Unstandardized Coefficients B.

Berdasarkan tabel ini diperoleh model persamaan regresi : $Y=\mathbf{1 7 , 9 9 0}+\mathbf{1 , 4 7 7} \mathbf{X}_{\mathbf{1}}$.

Penelitian yang bertujuan untuk mencari hubungan antara variabel kesiapan mengajar, variable pelaksanaan praktik pengalaman lapangan dengan variable keterampilan dasar mengajar mahasiswa calon guru, yang dilakukan pada sekolah sekolah mitra UPT Microteachig FKIP UKAW. Hasil Pengujian Hipotesis yang pertama menunjukkan Nilai sig=0,003 lebih kecil dari $\alpha=0,05$ artinya ada hubungan positif dan signifikan yang dilihat dari besarnya koefisien korelasi sebesar 0,559 yang artinya memiliki hubugan pada kategori sedang. Besarnya kontribusi variable kesiapan mengajar terhadap keterampilan dasar mengajar mahasiswa PPL sebanyak 31,2 \%. Mahasiswa calon guru perlu meningkatkan kesiapan diri sebelum melaksanakan pengajaran dengan tujuan agar dalam pelaksanaan pembelajaran di kelas dapat dilakukan dengan keterampilan dasar mengajar yang memadai. Hasil penelitian yang dilakukan Setiawan \& Mulyati 
416 Hubungan Kesiapan Mengajar dan Proses Praktik Pengalaman Lapangan dengan Keterampilan Dasar Mengajar Mahasiswa Pendidikan Biologi - Agus Maramba Meha, Novi Ivonne Bullu

DOI: https://doi.org/10.31004/edukatif.v3i2.323

(2018) menunjukan efektivitas Pembelajaran Microteaching berpengaruh secara langsung terhadap Kesiapan mengajar dan juga keterampilan mengajar berpengaruh secara langsung terhdap kesiapan mengajar sebesar.

Dengan penguasaan keterampilan dasar mengajar seorang guru akan dapat menyampaikan materi pembelajaran secara baik dan dapat mebimbing serta mengevaluasi proses belajar peserta didik dengan baik, hal ini tentu mewajibkan seorang mahasiswa calon guru untuk melakukan kesiapan sebelum melaksanakan pembelajaran di kelas. Kesiapan seseorang juga berkaitan dengan minat seseorang terhadap suatua aktivitas yang dilakukan. Sebagaimana hasil penelitian yang dilakukan oleh Wahyudi \& Syah, (2018) menunjukkan terdapat korelasi yang kuat antara minat menjadi guru terhadap kesiapan mengajar mahasiswa calon guru.

Kesiapan mengajar dapat dilakukan secara dini di kampus yaitu melalui program matakuliah microteaching dapat dilakukan secara baik dan disiplin. Penelitian yang dilakukan Mulyani et al., (2019) menunjukkan bahwa pembelajaran mikro berpengaruh positif terhadap kesiapan mengajar PPL mahasiswa Pendidikan Akuntansi 2014 UPI. Lebih lanjut penelitian yang dilakkukan oleh Agustina \& Saputra, (2017) menyimpulkan bahwa skor capaian keterampilan dasar mengajar pada matakuliah microteaching mengalami peningkatan pada kedua tampilan latihan mengajar. Oleh karena itu perlu bagi LPTK mengelolah secara baik program microteaching agar mahasiswa calon guru dapat mempersiapakan diri secara baik sebelum ditugaskan ke sekolah untuk melaksanakan PPL.

Table 3. Hubungan antara proses pelaksanaan PPL dengan keterampilan dasar mengajar mahasiswa PPL

\begin{tabular}{llrr}
\hline & & $\begin{array}{c}\text { Proses } \\
\text { PPL }\end{array}$ & \multicolumn{2}{c}{$\begin{array}{c}\text { Ketrampilan Dasar } \\
\text { Mengajar }\end{array}$} \\
\hline Proses PPL & Pearson Correlation & 1 & $.533^{* *}$ \\
& Sig. (2-tailed) & & .005 \\
& $\mathrm{~N}$ & 26 & 26 \\
$\begin{array}{l}\text { Ketrampilan dasar } \\
\text { mengajar }\end{array}$ & Pearson Correlation & $.533 * *$ & 1 \\
& Sig. (2-tailed) & .005 & 26 \\
\hline & $\mathrm{N}$ & 26 & \\
\hline
\end{tabular}

**. Correlation is significant at the 0.01 level (2-tailed).

Nilai sig $=0,005$ lebih kecil dari $\alpha=0,05 \mathrm{Hal}$ ini berarti ada hubungan positif dan signifikan antara antara proses pelaksanaan PPL dengan keterampilan dasar mengajar mahasiswa PPL. Besarnya KOEFISIEN KORELASI $=0,533$ berada pada kategori sedang. Besarnya kontribusi variable proses pelaksanaan PPL terhadap keterampilan dasar mengajar mahasiswa PPL sebanyak:

$$
\begin{aligned}
\mathrm{KP} & =\mathrm{r}^{2} \times 100 \% \\
& =0,533^{2} \times 100 \% \\
& =28,4 \%
\end{aligned}
$$

Artinya keterampilan mengajar mahasiswa PPL ditentukan oleh 28,4\% pelaksanaan PPL mereka dan kontribusi variable lain sebesar $100 \%-28,4 \%=71,6 \%$ 
Table 4. Koefisien regresi $\left(\right.$ Coefficients $^{\mathrm{a}}$ )

\begin{tabular}{|c|c|c|c|c|c|c|}
\hline \multirow[t]{2}{*}{ Model } & & \multicolumn{2}{|c|}{$\begin{array}{l}\text { Unstandardized } \\
\text { Coefficients }\end{array}$} & $\begin{array}{l}\text { Standardized } \\
\text { Coefficients }\end{array}$ & \multirow[t]{2}{*}{$\mathbf{T}$} & \multirow[t]{2}{*}{ Sig. } \\
\hline & & $\mathrm{B}$ & Std. Error & Beta & & \\
\hline \multirow[t]{2}{*}{1} & (Constant) & 23.558 & 23.747 & & .992 & .331 \\
\hline & $\begin{array}{l}\text { Proses } \\
\text { PPL }\end{array}$ & .942 & .305 & .533 & 3.088 & .005 \\
\hline
\end{tabular}

Dependent Variable: Ketrampilan Dasar Mengajar

Tabel 5. di atas menginformasikan model persamaan regresi yang diperoleh dengan koefisien konstanta dan koefisien variabel yang ada di kolom Unstandardized Coefficients B.

Berdasarkan tabel ini diperoleh model persamaan regresi : $\mathbf{Y}=\mathbf{2 3 , 5 5 8}+\mathbf{0 , 9 4 2} \mathbf{X}_{\mathbf{1}}$.

Selain kesiapan mengajar, seorang mahasiswa calon guru juga perlu mencari pengalaman dari berbagai kegiatan belajar dan praktik baik di kampus maupun yang dilakukan di luar kampus. Salah satu kegiatan yang dilakukan di luar kampus adalah praktik pengalama lapangan. Praktek pengalaman lapangan bertujuan untuk meningkatkan pengalaman dan keterampilan mahasiswa calom guru dalam melaksanakan pengajaran di kelas yang nyata. Hasil analisis pengujian hipotesisi yang kedua menunjukan Nilai sig $=0,005$ lebih kecil dari $\alpha=$ 0,05 artinya ada hubungan positif dan signifikan antara antara proses pelaksanaan PPL dengan keterampilan dasar mengajar mahasiswa PPL. Besarnya koefisien korelasi sebesar 0,533 itu artinya berada pada kategori sedang. Besarnya kontribusi pelaksanaan PPL terhadap peningkatan keterampilan dasar mengajar mahasiswa calon guru sebesar $28,4 \%$. Kegiatan PPL perlu ditingkatkan dan perlu ditambahkan masa pelaksanaannya di sekolah yang biasanya dilakukan kurang lebih 3 bulan agar dapat dilakukan selama 1 semester.

Dengan pelaksanaan PPL selama 1 semester mahasiswa calon guru benar-benar mendapatkan pengalaman mengajar yang banyak dalam rangka kesiapan dirinya menjadi seorang guru yang berkompeten. Dengan adanya kegiatan PPL tentu sangat mendukung kesiapan mahasiswa menjadi seorang calon guru yang professional. Hasil penelitian yang dilakukan Novitasari et al., (2013) menunjukan dengan pelaksanaan PPL tingkat kualitas penguasaan kompetensi mengajar mahasiswa sudah baik secara keseluruhan, khusus kompetensi pedagogic sebesar $77,18 \%$. Pedagogic merupakan salah satu kompetensi yang wajib dimiliki oleh seorang guru maupun mahasiswa calon guru, karena kompetensi ini berkaitan dengan keterampilan dasar mengajar seorang guru. Kurangnya persiapan mahasiwa dalam menghadapi PPL dapat menyebab komptensi pedagogic yang dimiliki rendah, hasil penelitian Korlianda et al., (2019) menunjukkan kontribusi kompetensi pedagogik Mahasiswa PPL di SMP Negeri 10 Kota Kupang terhadap hasil belajar siswa hanya sebesar 12\% .

Table 5. Hubungan antara kesiapan mengajar dan proses pelaksanaan PPL dengan keterampilan dasar mengajar mahasiswa PPL (Model Summary)

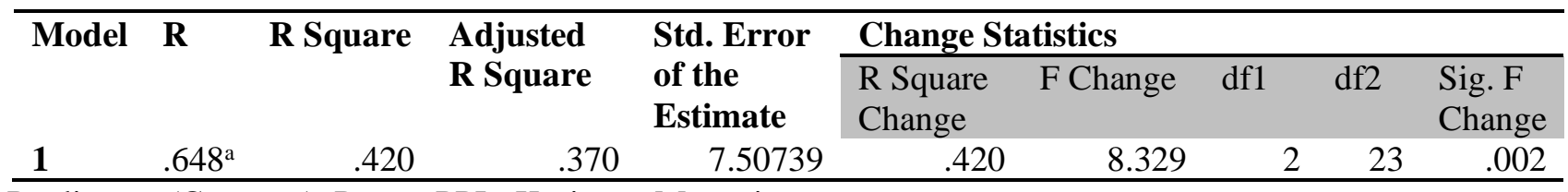

Predictors: (Constant), Proses PPL, Kesiapan Mengajar

Berdasarkan Nilai sig. F Change diperoleh sebesar 0,002 lebih kecil dari nilai $\alpha=0,05$ Artinya terdapat hubungan positif dan signifikan antara kesiapan mengajar dan proses pelaksanaan PPL dengan keterampilan dasar mengajar mahasiswa PPL. Selanjutanya kontribusi kedua variable bebas terhadap variable terikat:

Nilai $\quad \mathrm{R}$ sebesar 0,648

$\mathrm{R}^{2}$ sebesar 0,420

Edukatif : Jurnal Ilmu Pendidikan Vol 3 No 2 Tahun 2021 p-ISSN 2656-8063 e-ISSN 2656-8071 
Artinya kontribusi kesiapan mengajar dan proses pelaksanaan PPL dengan keterampilan dasar mengajar mahasiswa PPL adalah sebesar $0,420 \times 100 \%=42 \%$, Atau dengan kata lain $42 \%$ perubahan keterampilan dasar mengajar mahasiswa ditentukan oleh kesiapan mengajar dan proses pelaksanaan PPL, sedangkan 58\% ditentukan oleh variable lain yang tidak diteliti.

Table 6. koefesien regresi (Coefficients $\left.{ }^{\mathrm{a}}\right)$

\begin{tabular}{|c|c|c|c|c|c|c|}
\hline \multirow{2}{*}{\multicolumn{2}{|c|}{ Model }} & \multicolumn{2}{|c|}{$\begin{array}{l}\text { Unstandardized } \\
\text { Coefficients }\end{array}$} & \multirow{2}{*}{$\begin{array}{c}\begin{array}{l}\text { Standardized } \\
\text { Coefficients }\end{array} \\
\text { Beta }\end{array}$} & \multirow{3}{*}{$\begin{array}{c}\mathbf{t} \\
-1.074\end{array}$} & \multirow{3}{*}{$\begin{array}{l}\text { Sig. } \\
.29\end{array}$} \\
\hline & & B & Std. Error & & & \\
\hline \multirow[t]{3}{*}{1} & (Constant) & 36.309 & 33.811 & & & \\
\hline & $\begin{array}{l}\text { Kesiapan } \\
\text { Mengajar }\end{array}$ & 1.074 & .463 & .406 & 2.319 & .030 \\
\hline & Proses PPL & .639 & .309 & .362 & 2.066 & .050 \\
\hline
\end{tabular}

Dependent Variable: keterampilan dasar menagajar

Tabel di atas menginformasikan model persamaan regresi yang diperoleh dengan koefisien konstanta dan koefisien variabel yang ada di kolom Unstandardized Coefficients B. Berdasarkan tabel ini diperoleh model persamaan regresi : $Y=36,309+1,074 X_{1}+0,639 X_{2}$.

Kesiapan seorang mahasiswa calon guru dan pelakasanaan PPL di sekolah sangat berperan dalam meningkatkan kemampuan dan keterampilan dasar dalam mengajar. Berdasarkan hasil pengujian hipotesis yang ke 3 menunjukan terdapat hubungan positif dan signifikan antara kesiapan mengajar dan proses pelaksanaan PPL dengan keterampilan dasar mengajar mahasiswa PPL yang dilihat dari Nilai sig. F Change sebesar 0,002 lebih kecil dari nilai $\alpha=0,05$. kontribusi kesiapan mengajar dan proses pelaksanaan PPL dengan keterampilan dasar mengajar mahasiswa PPL adalah sebesar 42\% Atau dengan kata lain $42 \%$ perubahan keterampilan dasar mengajar mahasiswa ditentukan oleh kesiapan mengajar dan proses pelaksanaan PPL, sedangkan 58\% ditentukan oleh variable lain yang tidak diteliti.

Keterampilan dasar mengajar menjadi penting untuk dimiliki dan dikuasai oleh seorang guru sebelum melaksanakan pembelajaran. Sebagaimana yang dijelaskan Sundari \& Muliyawati (2017) bahwa keterampilan dasar mengajar merupakan keterampilan yang bersifat khusus yang harus dimiliki oleh guru, dosen, instruktur atau pengajar lainnya agar dapat melaksanakan tugas mengajar secara efektif, efesien dan professional. Mahasiswa sebagai calon guru perlu disiapkan secara matang melalui berbagai kegiatan dan program pengajaran di kampus, maupun diluar kampus, selanjutnya mahasiswa juga harus mempersiapkan diri dengan terus belajar dan berlatih agar keterampilan dasar mengajar sebagai seorang calon guru dapat terbentuk dengan baik.

Selain persiapan mahasiswa itu sendiri yang dapat menentukan pembentukan keterampilan dasar mengajar, dosen dan guru pamong juga memiliki peran dalam pembentukannya melalui proses pendampingan, bimbingan, pengarahan kepada mahasiwa calon guru selama PPL disekolah. Sejalan dengan penelitian yang dilakukan oleh Mukhibad \& Susilowati, (2010) Menunjukkan terdapat hubungan antara peran dosen pembimbing dan guru pamong terhadap keberhasilan PPL mahasiswa Pendidikan Akuntansi Tahun 2007. Selanjutnya penelitian yang dilakukan Yusuf \& Dwijayanti, (2019) menyatakan terdapat pengaruh guru pamong dan dosen pendamping terhadapat keberhasilan PPL, bahwa semakin baik guru pamong dan dosen melakukan bimbingan semakin baik pula keberhasilan mahasiswa dalam melaksanakan PPL. 
419 Hubungan Kesiapan Mengajar dan Proses Praktik Pengalaman Lapangan dengan Keterampilan Dasar Mengajar Mahasiswa Pendidikan Biologi - Agus Maramba Meha, Novi Ivonne Bullu

DOI: https://doi.org/10.31004/edukatif.v3i2.323

\section{KESIMPULAN}

Merujuk pada hasil penelitian dan pembahasan dapat disimpulkan bahwa kesiapan seorang mahasiswa calon guru dan pelakasanaan PPL di sekolah sangat berperan dalam meningkatkan kemampuan dan keterampilan dasar dalam mengajar. Hasil analisis menunjukan terdapat hubungan positif dan signifikan yang dilihat dari Nilai sig. F Change sebesar 0,002 lebih kecil dari nilai $\alpha=0,05$. dimana perubahan keterampilan dasar mengajar mahasiswa ditentukan oleh kesiapan mengajar dan proses pelaksanaan PPL sebesar 42\%, sedangkan 58\% ditentukan oleh variable lain yang tidak diteliti. Hal ini berarti bahwa pembentukan peningkatan keterampilan dasar mengajar mahasiswa calon guru sangat ditentukan oleh kesiapan mahasiwa sejak mengikuti proses perkuliahan serta kesiapannya ketika mengikuti praktik pengalaman lapangan di sekolah. Artinya semakin baik kesiapan mengajar mahasiswa dalam pelaksanaan PPL maka akan semakin meningkat keterampilan dasar mengajarnya.

\section{UCAPAN TERIMA KASIH}

Peneliti mengucapkan terimakasih kepada: (a) DRPM Ditjen Penguatan Risbang, atas bantuan dana hibah Penelitian Dosen Pemula tahun 2019 yang diberikan kepada peneliti sehingga penelitian ini dapat diselesaikan; (b) sekolah mitra tempat pelaksanaan praktek pengalaman yang telah mengijinkan untuk melakukan penelitian; (c) Program Studi Pendidikan Biologi UKAW Kupang atas dukungan dalam pelaksanaan penelitian.

\section{DAFTAR PUSTAKA}

Agustina, P., \& Saputra, A. (2017). Profil Keterampilan Dasar Mengajar Mahasiswa Calon Guru Biologi pada

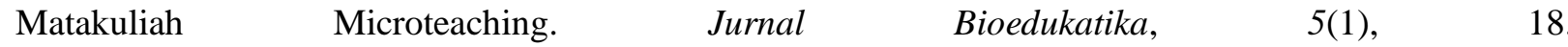
https://doi.org/10.26555/bioedukatika.v5i1.5670

Azizah, N., \& Rahmi, E. (2019). Persepsi Mahasiswa Tentang Peranan Mata Kuliah Micro Teaching Terhadap Kesiapan Mengajar Pada Mahasiswa Pendidikan Ekonomi Unp. Jurnal Ecogen, 2(2), 197. https://doi.org/10.24036/jmpe.v2i2.7312

Hapsari, P., \& Widhianningrum, P. W. (2013). Dampak Pelaksanaan Praktik Pengalaman Lapangan Terhadap Kinerja Mahasiswa Calon Guru (Studi Pada Program Studi Pendidikan Akuntansi IKIP PGRI Madiun). THE 2nd FORUM ILMIAH PENDIDIKAN AKUNTANSI, $1-13$. http://202.91.10.29/index.php/JIP/article/view/800

Korlianda, J., Adoe, Y., Meha, A. M., \& Foeh, Y. (2019). Hubungan Kompetensi Pedagogik Mahasiswa Ppl Dengan Hasil Belajar Siswa Pada Materi Getaran Dan Gelombang Kelas Viii Di Smp Negeri 10 Kota Kupang Tahun Ajaran 2018/2019. Indigenous Biologi; Jurnal Pendidikan Dan Sains Biologi, 2(3), 123 131. https://doi.org/10.33323/indigenous.v2i3.36

Mukhibad, H., \& Susilowati, N. (2010). Studi Evaluasi Kompetensi Mengajar Mahasiswa Praktek Pengalaman Lapangan (Ppl) Jurusan Akuntansi Universitas Negeri Semarang. Lembaran Ilmu Kependidikan, 39(2), 112-124.

Mulyani, H., Purnamasari, I., \& Rahmawati, F. (2019). Analisis Kesiapan Mengajar Program Pengalaman Lapangan Mahasiswa Pendidikan Akuntansi Melalui Pembelajaran Mikro. JPAK: Jurnal Pendidikan Akuntansi Dan Keuangan, 7(2), 147-156. https://doi.org/10.17509/jpak.v7i2.18086

Novitasari, F., Ngadiman, \& Sumaryati, S. (2013). Pengaruh Program Pengalaman Lapangan Terhadap Kesiapan Mahasiswa Prodi Ekonomi FKIP UNS Menjadi Tenaga Pendidik. Jupe UNS, 2(1), 1-13.

Samson, V. R., \& Vyjayanthi, S. (2020). Pre-University Teachers 'Teaching Skills Pre-University Teachers ' 
420 Hubungan Kesiapan Mengajar dan Proses Praktik Pengalaman Lapangan dengan Keterampilan Dasar Mengajar Mahasiswa Pendidikan Biologi - Agus Maramba Meha, Novi Ivonne Bullu DOI: https://doi.org/10.31004/edukatif.v3i2.323

Teaching Skills. November.

Setiawan, I., \& Mulyati, S. (2018). Efektivitas Mata Kuliah Pembelajaran Mikro (Microteaching) Terhadap Keterampilan Dasar Mengajar Dan Kesiapan Mengajar. Equilibrium: Jurnal Penelitian Pendidikan Dan Ekonomi, 15(2), 16-33. https://doi.org/10.25134/equi.v15i02.Abstract

Sumarni, S. (2020). Pengaruh Pemahaman Knowledge Sharing terhadap Prestasi Mahasiswa yang Melaksanakan Praktek Pengalaman Lapangan (Studi pada Mahasiswa STKIP Nasional Padang Pariaman). Jurnal Ilmiah Dikdaya, 10(1), 78. https://doi.org/10.33087/dikdaya.v10i1.161

Sundari, F. S., \& Muliyawati, Y. (2017). Analisis Keterampilan Dasar Mengajar Mahasiswa PGSD. P e d a $g$ o $n$ a $L, 1(1), 26-36$.

Wahyudi, R., \& Syah, N. (2018). Hubungan minat menjadi guru dengan kesiapan mengajar mahasiswa Prodi Pendidikan Teknik bangunan. Jurnal Universitas Negeri Padang, 6(1), 1-5.

Wahyulestari, M. R. D. (2018). Keterampilan Dasar Mengajar Di Sekolah Dasar. Prosiding Seminar Nasional Penelitian, Pendidikan Dan Penerapan MIPA, 208.

Wardhani, M. K. (2020). Persepsi dan Kesiapan Mengajar Mahasiswa Guru Terhadap Anak Berkebutuhan Khusus dalam Konteks Sekolah Inklusi. Scholaria: Jurnal Pendidikan Dan Kebudayaan, 10(2), 152161. https://doi.org/10.24246/j.js.2020.v10.i2.p152-161

Yusuf, M., \& Dwijayanti, K. (2019). Kontribusi guru pamong, dosen pembimbing dan kepala sekolah terhadap pelaksanaan praktik pengalaman lapangan (PPL) mahasiswa PJKR di sekolah latihan. JURNAL ILMIAH PENJAS (Penelitian, Pendidikan Dan Pengajaran), 5(1), 1-13. http://202.91.10.29/index.php/JIP/article/view/800 